\title{
The effect of temperature and bulk composition on the solution mechanism of phosphorus in peraluminous haplogranitic magma
}

\author{
B.O. Mysen, ${ }^{1, *}$ F. Holtz, ${ }^{2, \dagger}$ M. PiChavant, ${ }^{2}$ J.-M. Beny, ${ }^{2}$ AND J.-M. MonTeL ${ }^{3}$ \\ ${ }^{1}$ Geophysical Laboratory and Center for High Pressure Research, Carnegie Institution of Washington, 5251 Broad Branch Road, \\ N.W., Washington, D.C. 20015, U.S.A. \\ ${ }^{2}$ CRSCM-CNRS, 1a, rue de la Ferollerie, 45071 Orleans, France \\ ${ }^{3}$ Department de Geologie, URA 10 du CNRS, Universite Blaise Pascal, 5 rue Kessler, 63038 Clermont-Ferrand, France
}

\begin{abstract}
Solution mechanisms of $\mathrm{P}$ in peraluminous glasses and melts in the system $\mathrm{CaO}-\mathrm{Na}_{2} \mathrm{O}-\mathrm{K}_{2} \mathrm{O}-\mathrm{Al}_{2} \mathrm{O}_{3}$ $\mathrm{SiO}_{2}-\mathrm{P}_{2} \mathrm{O}_{5}$ have been examined with in-situ microRaman spectroscopy from ambient temperature to near $1200{ }^{\circ} \mathrm{C}$. The principal aim was to examine the relative stabilities of phosphate complexes as functions of $\mathrm{P}$ content, peraluminosity, and temperature. Increasing peraluminosity was accomplished by increasing the proportions of $\mathrm{Al}^{3+}$ and $\mathrm{Ca}^{2+}$ of constant $\mathrm{SiO}_{2}$ content. The molar ratio $\mathrm{Al}_{2} \mathrm{O}_{3} /$ $\left(\mathrm{CaO}+\mathrm{Na}_{2} \mathrm{O}+\mathrm{K}_{2} \mathrm{O}\right)(\mathrm{A} / \mathrm{CNK})$ ranged from $\sim 1$ to $\sim 1.3$.

In all compositions, $\mathrm{P}^{5+}$ is bonded to $\mathrm{Al}^{3+}$ to form $\mathrm{AlPO}_{4}$ complexes. In addition, there is evidence for pyrophosphate complexing $\left(\mathrm{P}_{2} \mathrm{O}_{7}\right)$. In melts with the highest $(\mathrm{Ca}+\mathrm{Na}+\mathrm{K}) / \mathrm{P}$, there is probably also a small fraction of orthophosphate complexes present. The relative importance of $\mathrm{AlPO}_{4}$-like complexes is correlated positively with peraluminosity (A/CNK), $\mathrm{P}_{2} \mathrm{O}_{5}$ content, and increasing temperature at temperatures above that of the glass transition. These structural relationships among phosphate complexes are coupled with decreasing polymerization of the aluminosilicate melts.
\end{abstract}

\section{INTRODUCTION}

Phosphorus in igneous rocks is important for at least two main reasons. First, in the concentration range in natural magmas $\left(<2-3\right.$ wt $\left.\% \mathrm{P}_{2} \mathrm{O}_{5}\right)$, phosphorus strongly modifies both physical and chemical properties of the magmatic system. These properties include melt viscosity (Dingwell et al. 1993; Toplis et al. 1994), liquidus phase relations (Wyllie and Tuttle 1964; Kushiro 1975; Ryerson 1985; London et al. 1993), redox equilibria of iron (e.g., Mysen 1992; Gwinn and Hess 1993; Toplis et al. 1994), and element partitioning (Watson 1976). Second, phosphate minerals (e.g., apatite and monazite) in some cases are abundant in highly evolved igneous systems (e.g., Pichavant et al. 1987; London 1987; London et al. 1990). Such minerals in equilibrium with a P-bearing magma can alter the trace-element patterns of the magma significantly without much impact on its major element composition (e.g., Watson 1980; Green and Watson 1982; Ghazot et al. 1996). Consequently, phosphorus solution mechanisms and their relations to saturation of phosphate minerals in aluminosilicate melts require characterization.

To characterize the behavior of P-bearing magmas and the crystallization behavior of phosphate minerals from such magmas, data on solubility and solubility mechanisms of $\mathrm{P}$ in the magmatic liquid are required. For subaluminous $(\mathrm{A} / \mathrm{CNK}=1)$ and peraluminous $(\mathrm{A} / \mathrm{CNK}>1)$ glass, it has been suggested that the speciation of $\mathrm{P}$ is dominated by the presence of $\mathrm{AlPO}_{4}$-like units (Mysen et al. 1981; Kosinski et al. 1988; Dupree et al.

*E-mail: mysen@gl.ciw.edu

$\dagger$ Now at: Institute of Mineralogie, University of Hannover, Welfengarten 1, D-30167 Hannover, Germany.
1989; Gan and Hess 1992; Toplis and Dingwell 1996; Mysen et al. 1997; Toplis and Schaller 1998). Complexing of $\mathrm{P}^{5+}$ with $\mathrm{Al}^{3+}$ in peraluminous aluminosilicate melts would account for the strong increase of apatite solubility with increasing $\mathrm{A} / \mathrm{CNK}$ found experimentally (Pichavant et al. 1992; Wolf and London 1994). Formation of such Al-rich phosphate complexes in melts might also help explain the expansion of the quartz liquidus volume relative to that of feldspar in haplogranite systems (London et al. 1993).

These studies were, however, conducted on glasses at ambient temperature. The application of these structural data to that of their melt relies on assumptions of structural similarity between a melt and its glass. Recent data on melts in the system $\mathrm{Na}_{2} \mathrm{O}-\mathrm{Al}_{2} \mathrm{O}_{3}-\mathrm{SiO}_{2}-\mathrm{P}_{2} \mathrm{O}_{5}$ have demonstrated, however, that phosphate and silicate speciation changes rapidly with increasing temperature across the glass transition (Mysen 1996, 1998a). Therefore, to provide structural data on melts obtained in-situ at magmatic temperatures, we present here Raman spectroscopic data on the solution mechanisms of $\mathrm{P}_{2} \mathrm{O}_{5}$ in peraluminous melts in the system $\mathrm{SiO}_{2}-\mathrm{Al}_{2} \mathrm{O}_{3}-\mathrm{Na}_{2} \mathrm{O}-\mathrm{K}_{2} \mathrm{O}-\mathrm{CaO}-$ $\mathrm{P}_{2} \mathrm{O}_{5}$ from room temperature to those above their liquidii. Data are reported for two series of melts, one with $\mathrm{Ca} / \mathrm{P}=5 / 3$ (i.e., same as in apatite) and the other with $\mathrm{Ca} / \mathrm{P}=1$, which enables us to test the possibility that $\mathrm{P}$ coordinates preferentially with Ca rather than with Al.

\section{EXPERIMENTAL METHODS}

Starting composition glasses (Table 1) were from the same batches as those for which Mysen et al. (1997) reported structural information of $\mathrm{H}_{2} \mathrm{O}$-free and $\mathrm{H}_{2} \mathrm{O}$-bearing glasses at $25^{\circ} \mathrm{C}$. Details of starting glass preparation and chemical analysis are 
TABLE 1. Composition of starting materials (wt\%)*

\begin{tabular}{lrrrrrrrr}
\hline \hline & 244 & 245 & 246 & 247 & 248 & 249 & 250 & 251 \\
\hline $\mathrm{SiO}_{2}$ & 75.97 & 75.79 & 74.89 & 75.05 & 75.69 & 75.92 & 75.56 & 75.48 \\
$\mathrm{Al}_{2} \mathrm{O}_{3}$ & 13.88 & 14.21 & 14.48 & 15.11 & 13.93 & 14.04 & 14.06 & 14.31 \\
$\mathrm{CaO}$ & 0.21 & 1.46 & 2.90 & 3.32 & 0.09 & 0.88 & 1.63 & 2.33 \\
$\mathrm{Na}_{2} \mathrm{O}$ & 3.92 & 2.96 & 2.19 & 1.62 & 3.92 & 3.16 & 2.64 & 1.99 \\
$\mathrm{~K}_{2} \mathrm{O}$ & 5.89 & 4.47 & 3.28 & 2.34 & 6.22 & 4.92 & 3.88 & 3.03 \\
$\mathrm{P}_{2} \mathrm{O}_{5}$ & 0.13 & 1.11 & 2.27 & 2.55 & 0.15 & 1.08 & 2.24 & 2.86 \\
$\mathrm{~A} / \mathrm{CNK}$ & 1.07 & 1.15 & 1.17 & 1.34 & 1.05 & 1.16 & 1.22 & 1.33 \\
\hline${ }^{*} \mathrm{The} \mathrm{samples} \mathrm{were} \mathrm{synthesized} \mathrm{under} \mathrm{water-saturated} \mathrm{conditions} \mathrm{at}$ \\
0.4-0.8 GPa as described in Mysen et al (1997). These were subse- \\
quently dehydrated after loading onto the microheater used for high- \\
temperature experiments. In the table, the compositions have been \\
recalculated to 100 \% (anhydrous) The original electron microprobe \\
analyses data are given in Mysen et al. (1997). \\
l一
\end{tabular}

given in that paper and will not be repeated here. Compositionally, the two series of glasses evolve with concurrent increases in $\mathrm{A} / \mathrm{CNK}$ and $\mathrm{P}_{2} \mathrm{O}_{5}$ content from the $\mathrm{P}$-free, near-metaluminous compositions (sample nos. 244 and 248; Table 1) to the most P-rich and peraluminous compositions (sample nos. 247 and 251: Table 1) (see also Fig. 1a). Under the assumption that any $\mathrm{Al}^{3+}$ in excess over that electrically charge-balanced in fourfold coordination acts as a network-modifier, increasing peraluminosity (increasing $\mathrm{A} / \mathrm{CNK}$ and $\mathrm{P}_{2} \mathrm{O}_{5}$ ) would also result in increasing depolymerization of the glasses and melts (Fig. 1b). ${ }^{1}$

Raman spectra were recorded with a Dilor XY confocal microRaman spectrometer equipped with a cryogenic Wright Model CCD 05-11-0-202 charge-coupled detector (CCD). The excitation source was the $514 \mathrm{~nm}$ line of a Coherent Innova Model 90-5 $\mathrm{Ar}^{+}$laser operating at several hundred milliwatts at the sample. Integration times ranged from 60 to $300 \mathrm{~s}$.

A glass chip weighing $~ 1 \mathrm{mg}$ was melted onto a micro-heater used for the high-temperature Raman spectroscopic experiments (Mysen and Frantz 1992, 1993). The temperature precision is $\pm 4{ }^{\circ} \mathrm{C}$, and the uncertainty $5-10{ }^{\circ} \mathrm{C}$ (Mysen and Frantz 1992; Richet et al. 1994). After an experiment, the glass was removed from the heater by placing the heater with the glass sample in HF. In this process, the glass is dissolved without destroying the microheater itself.

The original starting glasses were the hydrated samples used by Mysen et al. (1997). These samples were dehydrated with the microheater before high-temperature experiments by heating them to $>1000{ }^{\circ} \mathrm{C}$ for several minutes followed by temperature-quenching to glass. The anhydrous nature of these glasses was ascertained by recording spectra in the $3600 \mathrm{~cm}^{-1}$ range, which covers the range of $\mathrm{OH}$ stretching vibrations.

\footnotetext{
${ }^{1} \mathrm{Al}^{3+}$ without charge-balance in tetrahedral coordination has been suggested to form tri-clusters where $\mathrm{Al}^{3+}$ actually also has four oxygen ligands (Lacey 1963). Recently, it has also been suggested that in peraluminous melts, $\mathrm{Al}^{3+}$ may reside in structural entities involving fourfold, fivefold, and sixfold coordination with oxygen (Sato et al. 1991; Poe et al. 1992). For the present purposes, it is not necessary to know the exact structural position of $\mathrm{Al}$ in peraluminous melts other than the fact that the $\mathrm{Al}$ is not a part of the aluminosilicate glass and melt network.
}

Following the dehydration procedure, for each composition, this material was then subjected immediately to high-temperature Raman spectroscopy. A spectrum of glass at $25{ }^{\circ} \mathrm{C}$ was taken first. The sample was then brought to the highest temperature to start a series of high-temperature spectroscopic experiments. The temperature was then lowered and the next spectrum was acquired. Each series of experiments was finished by taking another spectrum of the glass at $25^{\circ} \mathrm{C}$.

Because the sample after a series of high-temperature Raman experiments cannot be removed from the microheater for chemical analysis without destruction of the heater itself, the composition of glasses after an experiment could not be determined directly. Instead, Raman spectra of glasses before and after an experiment were compared as described by Mysen (1996).
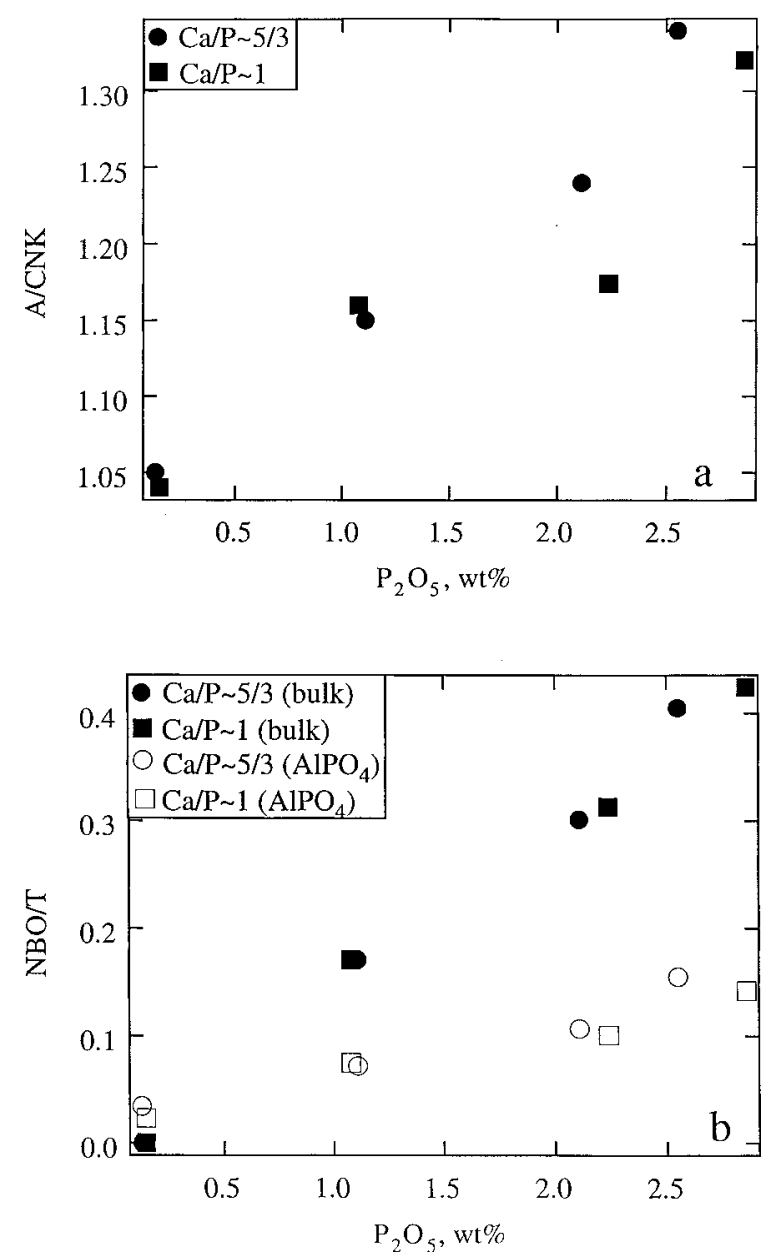

FIGURE 1. Relationships between weight percent of $\mathrm{P}_{2} \mathrm{O}_{5}$, peraluminosity (A/CNK) (a) and calculated NBO/T (b) of the starting materials. In $b$, the $\mathrm{NBO} / \mathrm{T}$ calculations were conducted under the assumption that any $\mathrm{Al}^{3+}$ in excess of that for which alkalis and alkaline earths are available for electrical charge-balance of $\mathrm{Al}$ in tetrahedral coordination is a network-modifier. Filled symbols denote the NBO/T calculated without consideration of excess $\mathrm{Al}^{3+}$ associated with $\mathrm{P}$. Open symbols denote the NBO/T calculated with all $\mathrm{P}$ associated with $\mathrm{Al}^{3+}$ as $\mathrm{AlPO}_{4}$ complexes. Only $\mathrm{Al}$ excess over $(\mathrm{Na}+\mathrm{K}+2 \mathrm{Ca}+\mathrm{P})$ is considered a network-modifier. 
The samples were monitored microscopically throughout each series of high-temperature experiments $(600 \times$ magnification). Nucleation and growth of bubbles or crystals would be observed immediately, but no such behavior occurred over the time scale of the experiments (60-120 minutes per series of high-temperature runs). The apatite saturation temperatures for these samples range between 750 and $800{ }^{\circ} \mathrm{C}$ (Pichavant et al. 1992). Therefore, in the lower-temperatures experiments, apatite would crystallize if sufficient time were provided to promote the onset of nucleation and growth. As no crystal formation was observed, that time is clearly longer than those of the experiments conducted here.
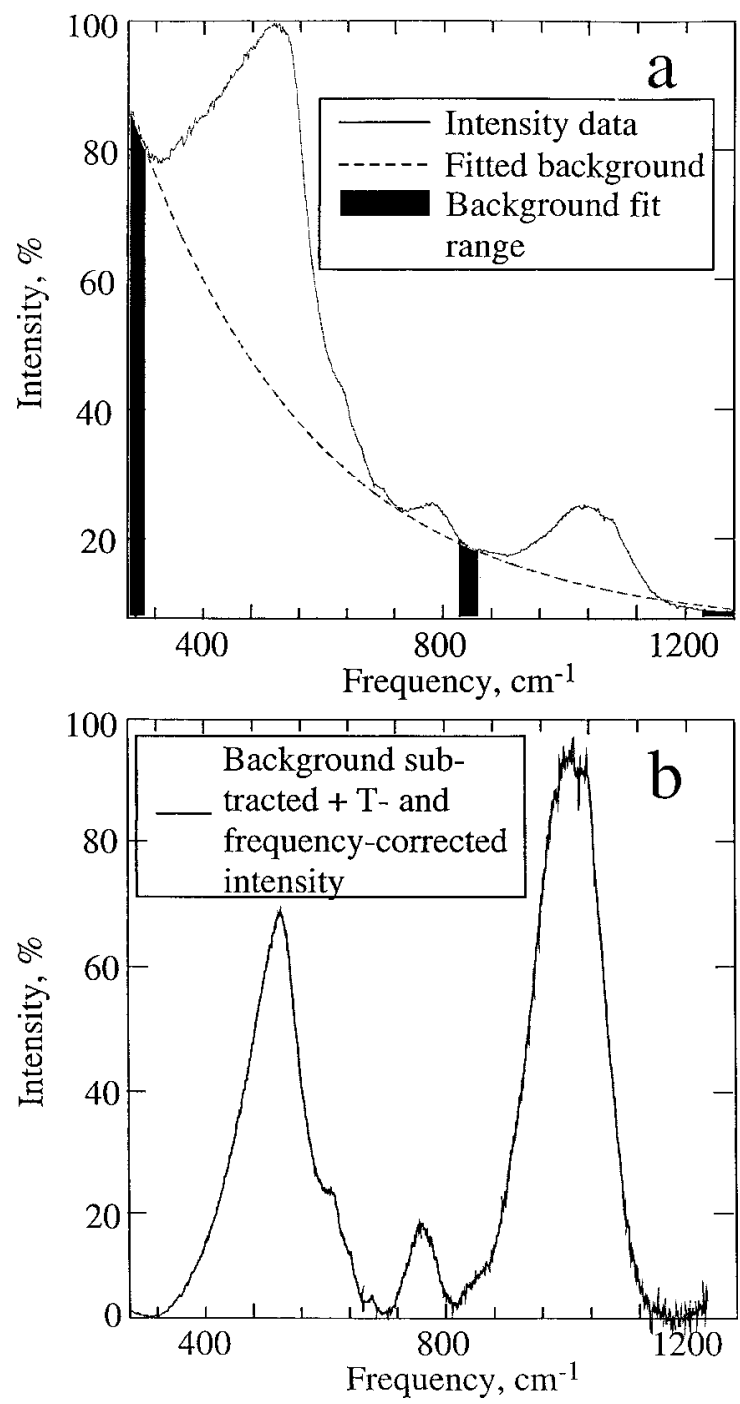

FIGURE 2. Background subtraction procedure with a spectrum of sample 251 at $\sim 1000{ }^{\circ} \mathrm{C}$ used as example. (a) Raw Raman data with fitted background shown as dotted line. Dark zones denote regions through which the background was fitted to an exponential function. (b) Spectrum resulting from subtraction of the background followed by correction for temperature- and frequency-dependent Raman intensity.
The raw Raman data were corrected for background as well as for temperature- and frequency-dependent scattering intensity (Fig. 2). In this procedure, the intensities first were converted to percent relative to the most intense data point in the spectrum followed by fitting an exponential background through portions of the spectra with no Raman intensity (Fig. 2a). This spectrum was then corrected for frequency- and temperaturedependent scattering intensity (Long 1977; Mysen et al. 1982), and these data were recalculated to percent relative to the most intense point in the corrected spectra. An example of a resulting spectrum is shown in Fig. $2 \mathrm{~b}$. It has been suggested that higher-order Raman scattering may contribute a few percent intensity to spectra of silicate and aluminosilicate melts at magmatic temperatures (e.g., Daniel et al. 1995; McMillan et al. 1994). However, within the several percent background scatter in the present data, there is no evidence for higher-order Raman bands.

\section{RESULTS}

\section{Spectroscopic data}

Raman spectra taken in-situ at the temperatures indicated on each spectrum are shown in Figure 3 (identified by sample number and corresponding $\mathrm{P}_{2} \mathrm{O}_{5}$ content in weight percent). These spectra, resembling those of other highly polymerized aluminosilicate glasses and melts (e.g., McMillan et al. 1982; Seifert et al. 1982; Daniel et al. 1995; Neuville and Mysen 1996), show distinct intensity features in a low-frequency region between $\sim 200$ and $\sim 650 \mathrm{~cm}^{-1}$, an intermediate region centered near $800 \mathrm{~cm}^{-1}$, and a high-frequency region between $\sim 800$ and $\sim 1300 \mathrm{~cm}^{-1}$.

The low-frequency region is centered near $500 \mathrm{~cm}^{-1}$, with an asymmetry toward lower frequency and with one or more weaker peaks or shoulders near $600 \mathrm{~cm}^{-1}$. Most of the intensity in this region can be assigned to vibrations within the three-imensionally interconnected (Si,Al)-O network (e.g., Daniel et al. 1995). The high-frequency portion of the spectra $\left(\sim 800-\sim 1300 \mathrm{~cm}^{-1}\right)$ covers the range that includes vibrations assigned to both $(\mathrm{Si}, \mathrm{Al})-\mathrm{O}$, $\mathrm{P}-\mathrm{O}$, and possible Al-O-P and Si-O-P vibrations.

To extract more detailed information on the effect of temperature in the high-frequency region, spectra of P-bearing samples were subtracted from those of samples having no phosphorus (Fig. 4). These difference spectra were then used as a guide in curvefitting the high-frequency region, a few examples of which are shown in Figure 5 (where bands that are shaded are those that do not occur in spectra of P-free glasses and melts). ${ }^{2}$

The difference spectra (Fig. 4) show three regions of interest. Both the $\mathrm{Ca} / \mathrm{P} \sim 5 / 3$ and $\mathrm{Ca} / \mathrm{P} \sim 1$ glass spectra exhibit a distinct intensity increase (compared with the spectra of P-free glass, no. 244 and 248) at or slightly below $1000 \mathrm{~cm}^{-1}$ (region A). This intensity appears to diminish or disappear, however, as the glasses are transformed to melts (see the $\sim 1000^{\circ} \mathrm{C} \mathrm{spec-}$

${ }^{2}$ The spectra were fitted to Gaussian lines with the commercial data manipulation program Igor from Wavemetrics. The deconvolution procedure was conducted subsequent to correction for temperature- and frequency-dependent Raman scattering (e.g., Long 1977). 

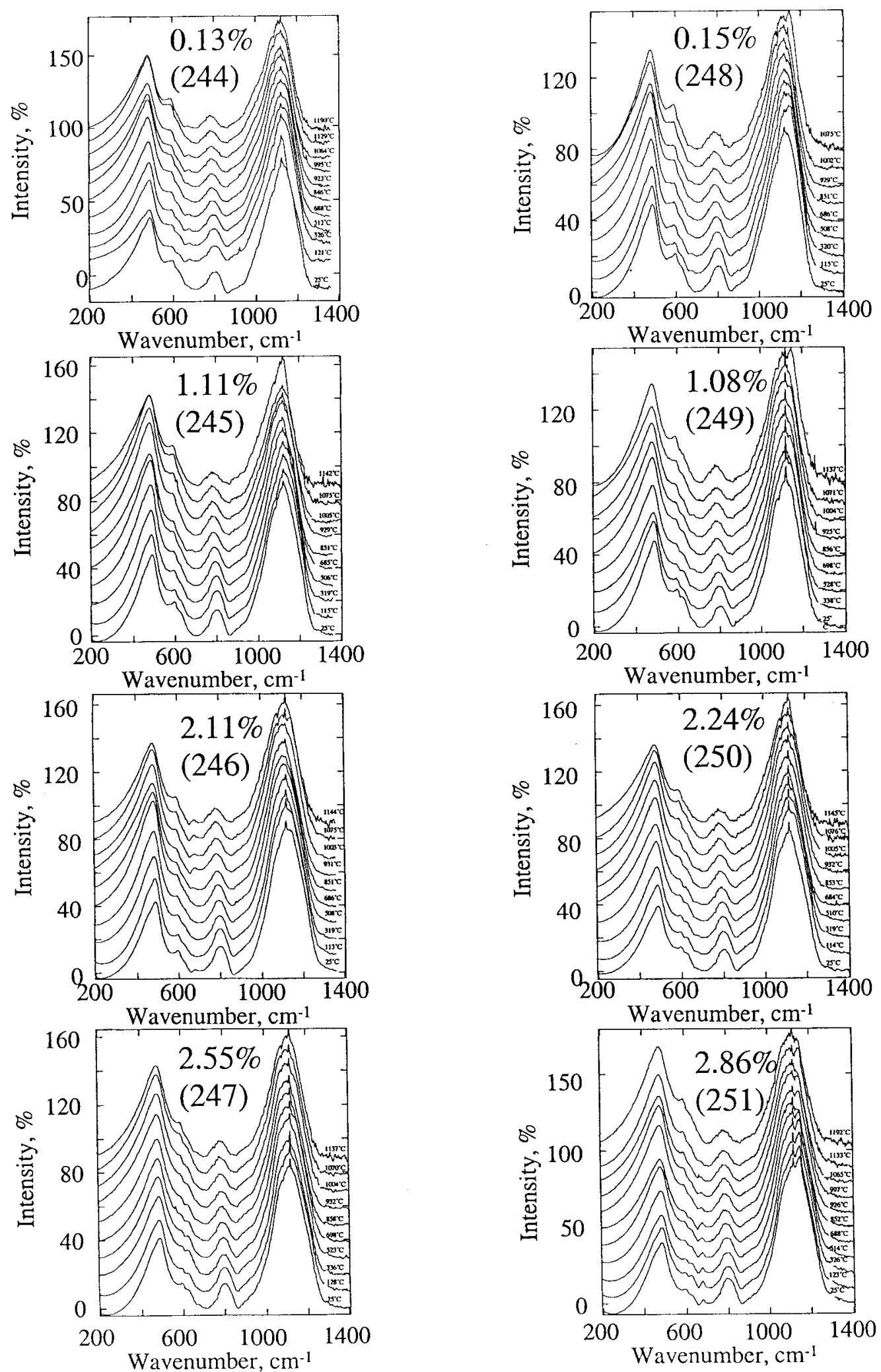

FIGURE 3. Unpolarized Raman spectra at temperatures indicated on the panels. The spectra are corrected for temperature- and frequencydependent scattering intensity as illustrated in Figure 2. Sample numbers are indicated in parentheses. Percent values denote weight percent of $\mathrm{P}_{2} \mathrm{O}_{5}$ from Table 1. Each spectrum is offset vertically for clarity. 

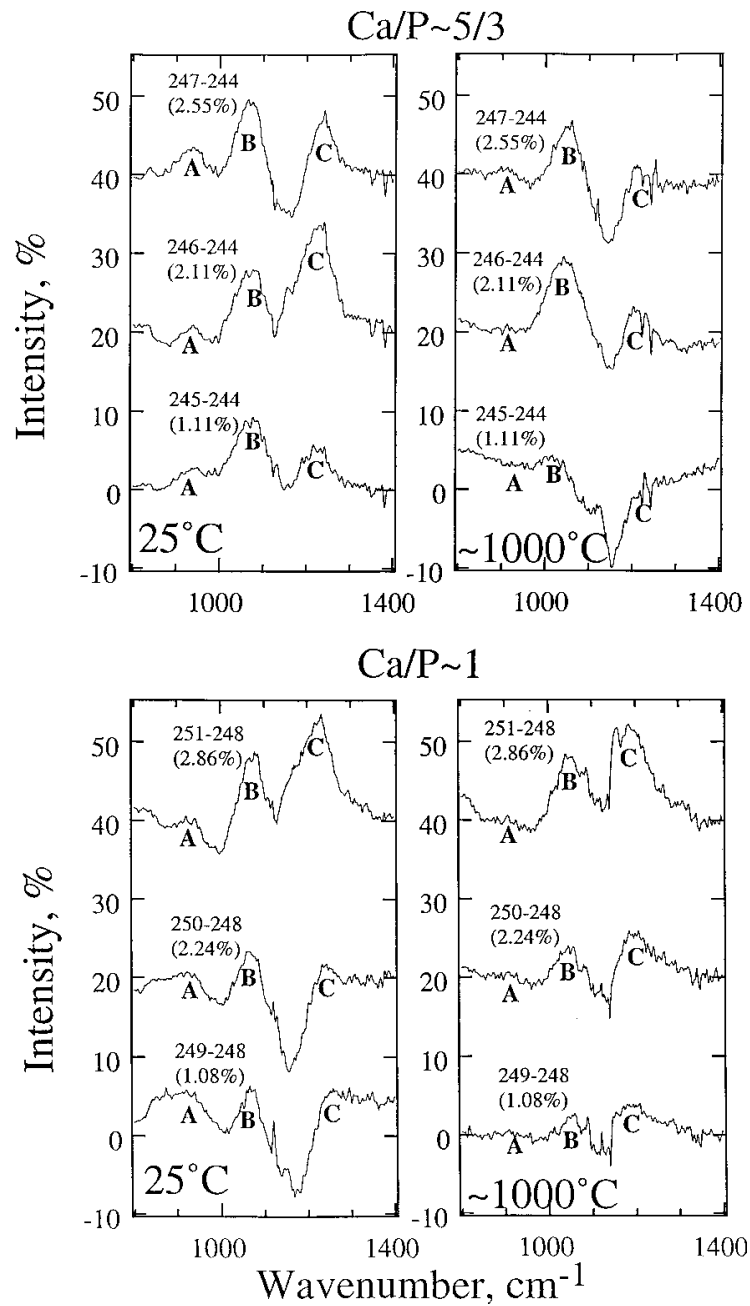

Figure 4. Difference Raman spectra at $25^{\circ} \mathrm{C}$ (glass) and $1000^{\circ} \mathrm{C}$ (liquid) of samples as indicated. Percent values in parentheses denote weight percent of $\mathrm{P}_{2} \mathrm{O}_{5}$ from Table 1. Each spectrum is offset vertically for clarity.

tra in Fig. 4). The spectra of all glasses and melts display a pronounced intensity increase between 1050 and $1080 \mathrm{~cm}^{-1}$ (region $B$; Fig. 4) an intensity increase that is positively correlated with P-content (and A/CNK). Finally, there is a distinct intensity increase in the glass spectra near $1250 \mathrm{~cm}^{-1}$, an intensity that increases with increasing P-content (and A/CNK) (Region $C$ ). This intensity is noticeably weaker in the spectra of melts, and more so in the melt spectra of the $\mathrm{Ca} / \mathrm{P} \sim 5 / 3$ series of compositions than in the spectra of melts from the $\mathrm{Ca} / \mathrm{P} \sim 1$ series of compositions.

In the curve-fitted spectra of melts and glasses (Fig. 5 shows examples at $25^{\circ} \mathrm{C}$ and $\sim 1070{ }^{\circ} \mathrm{C}$ ), the P-free samples (Fig. 5a and $5 \mathrm{~b}$ ) can be fitted for five Gaussian bands (although one near $900 \mathrm{~cm}^{-1}$ is normally so weak that its inclusion could not always be justified on statistical grounds). The spectra of the $\mathrm{Ca} / \mathrm{P} \sim 5 / 3$ series were fitted to seven bands and those of the $\mathrm{Ca} / \mathrm{P} \sim 1$ series of compositions to six bands (Fig. 5c, 5d, 5f, and 5g).
In the spectra of P-free glasses, the five bands in the highfrequency region occur near 795, 905, 1060, 1150, and 1200 $\mathrm{cm}^{-1}$ at $25^{\circ} \mathrm{C}$, and shift to lower frequencies with increasing temperature at a rate of $\leq 10^{-2} \mathrm{~cm}^{-1} /{ }^{\circ} \mathrm{C}$. These temperature-dependent frequency-shifts are within the range commonly reported for $(\mathrm{Si}, \mathrm{Al})-\mathrm{O}$ stretching vibrations in silicate glasses and crystals (e.g., McMillan et al. 1992; Mysen and Frantz 1993; Richet et al. 1994).

In the P-bearing glasses, the bands in the high-frequency region are near $800,900,950,995,1070,1120$, and $1150 \mathrm{~cm}^{-1}$ in the $\mathrm{Ca} / \mathrm{P} \sim 5 / 3$ series at $25^{\circ} \mathrm{C}$. In the $\mathrm{Ca} / \mathrm{P} \sim 1$ series, the band near $950 \mathrm{~cm}^{-1}$ is not observed. The temperature-dependent frequency shifts of the high-frequency bands of P-bearing glasses (Fig. 6) resemble those of the P-free glasses. An exception is the band near $1070 \mathrm{~cm}^{-1}$ for which $1 / v_{\mathrm{o}}(\partial v / \partial T) \sim-0.5 \cdot 10^{-5} / \mathrm{K}$ (where $v$ is frequency and $T$ is temperature). In the spectra of P-free glasses and melts, $1 / v_{0}(\partial v / \partial T) \sim-8 \cdot 10^{-5} / \mathrm{K}$ for the band in this frequency region.

\section{Band assignments}

The spectra of the P-free glasses and melts closely resemble those of other nearly or fully polymerized aluminosilicate materials (e.g., McMillan et al. 1982; Seifert et al. 1982; Daniel et al. 1995; Neuville and Mysen 1996). The bands in the 900$1200 \mathrm{~cm}^{-1}$ region are assigned to $(\mathrm{Si}, \mathrm{Al})-\mathrm{O}$ stretching within the three-dimensional network in accord with previous assignments (Seifert et al. 1982). The $800 \mathrm{~cm}^{-1}$ is assigned to in-cage oxygen motion in this network (e.g., McMillan et al. 1992). The bands in the low-frequency region are assigned to ( $\mathrm{Si}, \mathrm{Al})$ O-(Si,Al) rocking motions (e.g., Phillips, 1984).

The highest-frequency band, near $1150 \mathrm{~cm}^{-1}$, is assigned to $(\mathrm{Si}, \mathrm{Al})-\mathrm{O}^{\circ}$ in a fully polymerized $(\mathrm{Si}, \mathrm{Al})-\mathrm{O}$ network by analogy with assignments of the bands in spectra of glasses along the join $\mathrm{SiO}_{2}-\mathrm{NaAlO}_{2}$ (e.g., Seifert et al. 1982). The band near $1070 \mathrm{~cm}^{-1}$ corresponds to the intensity increase in region $B$ in Figure 4. The assignment of this band is somewhat uncertain. It occurs at a frequency similar to the band near $1060 \mathrm{~cm}^{-1}$ in the P-free glasses and melts. This band, however, is considerably more intense in the P-bearing samples (e.g., Fig. 5). Further, its $1 / v_{0}(\partial v / \partial T)$ value is about an order of magnitude less than for the $\sim 1060 \mathrm{~cm}^{-1}$ band in the spectra of P-free materials. The value of $1 / v_{0}(\partial v / \partial \mathrm{T})$ for the $\sim 1070 \mathrm{~cm}^{-1}$ band in spectra of P-bearing glasses and melts does, however, resemble that of a band at similar frequency in depolymerized $\mathrm{Na}_{2} \mathrm{O}-\mathrm{Al}_{2} \mathrm{O}_{3}-\mathrm{SiO}_{2}$ glasses and melts. In the spectra of those materials, the $\sim 1070$ $\mathrm{cm}^{-1}$ band was assigned to ( $\left.\mathrm{Si}, \mathrm{Al}\right)-\mathrm{O}^{-}$stretching in $\mathrm{Q}^{3}$-type structural units (Mysen 1995). Furthermore, relative to the intensity of the $1150 \mathrm{~cm}^{-1}$ band, its integrated intensity is correlated positively with peraluminosity (A/CNK) and total phosphorus content (Fig. 7) suggesting, therefore, that it stems from vibrations associated with structural features in the melts due to those compositional factors. In light of these observations, it is suggested that the band fitted near $1070 \mathrm{~cm}^{-1}$ in the spectra of Pbearing glasses and melts is dominantly that of a vibration assigned to $(\mathrm{Si}, \mathrm{Al})-\mathrm{O}^{-}$stretching (nonbridging oxygen) in $\mathrm{Q}^{3}$ structural units. It is possible, however, that the band as fitted also incorporates some intensity resulting from the presence of three-dimensionally interconnected structural units in the melts 

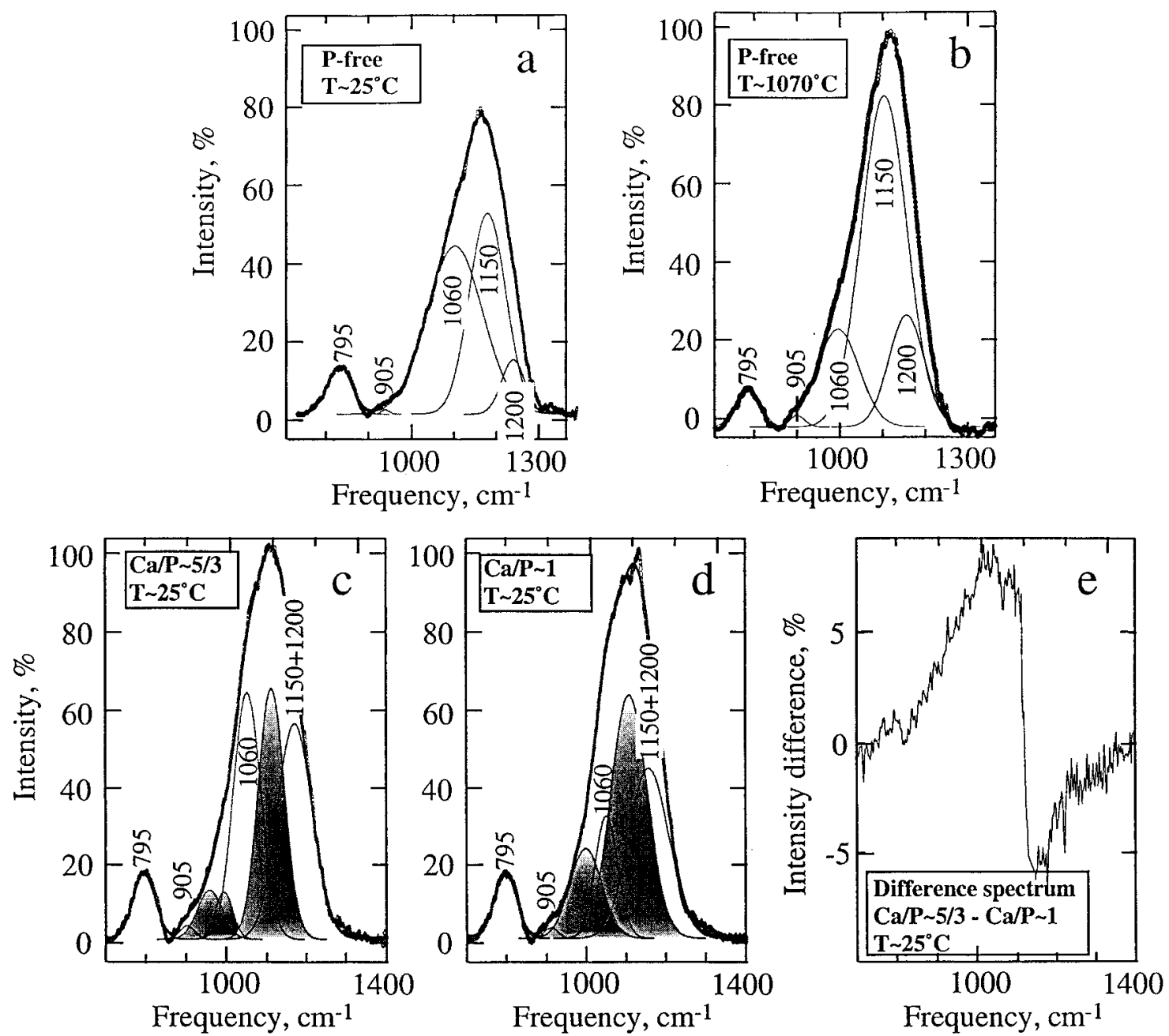

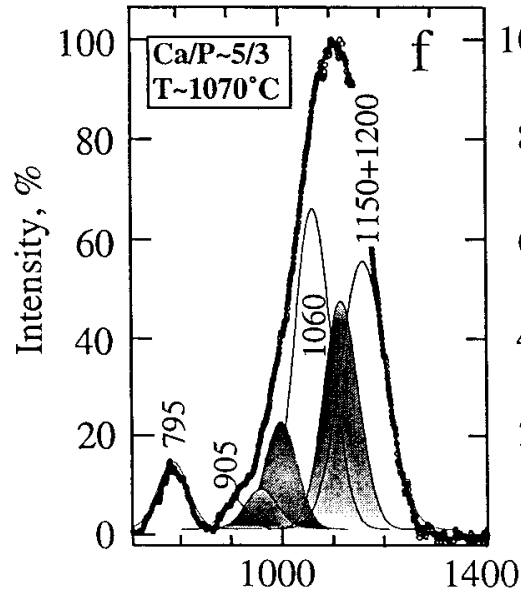

Frequency, $\mathrm{cm}^{-1}$
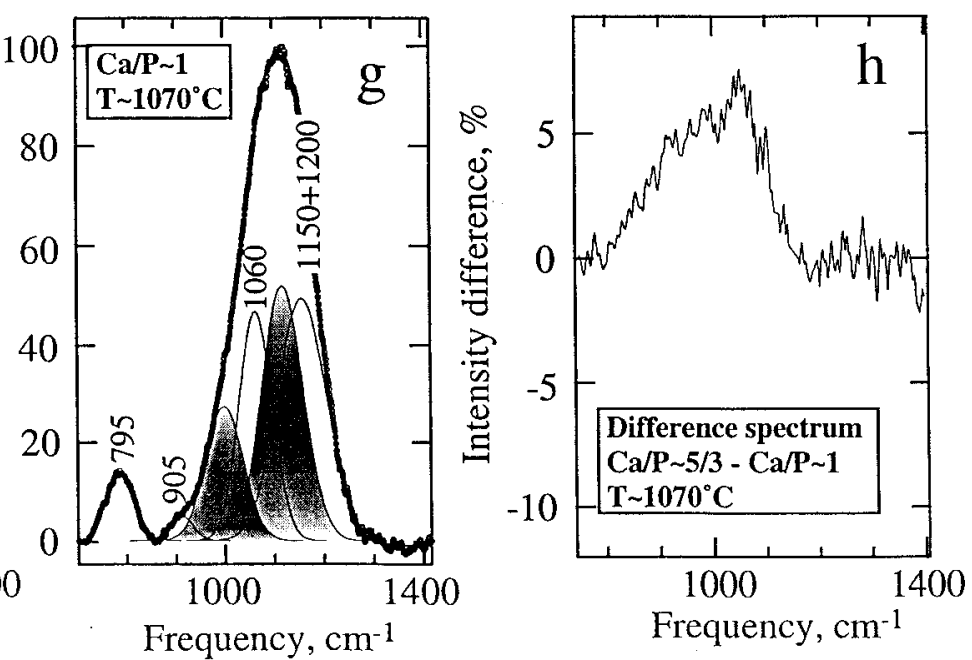

FIGURE 5. Examples of curve-fitted Raman spectra and glasses and melts in the high-frequency portion of the spectra. Shaded bands are those found only in samples that contain P. The bands identified with numbers (approximate frequency) are those that occur in spectra of both P-free and P-bearing samples. (a and b) Spectra of glass and melt of P-free composition 244. (c and d) Spectra of glasses at $25{ }^{\circ} \mathrm{C}$ of samples 247 and 251, respectively. (e) Difference spectrum showing the result of spectrum D subtracted from spectrum C. The intensity difference refers to the percentage intensities in spectra C and D. (f and g) Spectra of melts at $1070{ }^{\circ} \mathrm{C}$ for samples 247 and 251 , respectively. (h) Difference spectrum showing the result of spectrum $\mathrm{G}$ subtracted from spectrum $\mathrm{F}$. The intensity difference refers to the percentage intensities in spectra $\mathrm{F}$ and G. 


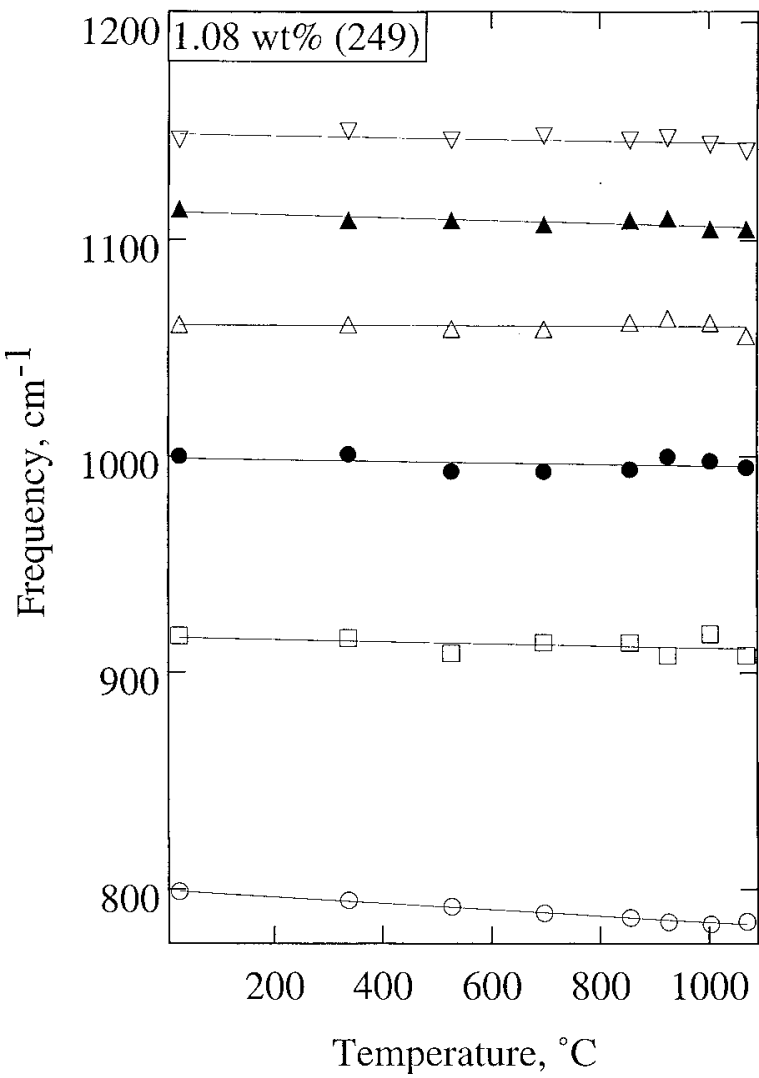

FIGURE 6. Example of temperature-dependence of Raman bands in the high-frequency envelope. Sample $249\left(1.08 \mathrm{wt} \% \mathrm{P}_{2} \mathrm{O}_{5}\right)$ is used as an example. Closed symbols denote bands found only in samples that contain phosphorus. Open symbols denote bands found in all samples. The lines are results of least-squares regression through the data.

and glasses. That possibility cannot be resolved within the errors of the deconvolution procedure.

The bands near 950, 1000, and $1120 \mathrm{~cm}^{-1}$ (shaded in the examples in Fig. 5) occur only in spectra of P-bearing samples. Among these, the $950 \mathrm{~cm}^{-1}$ band occurs only in spectra from samples of the $\mathrm{Ca} / \mathrm{P} \sim 5 / 3$ series, but even in those spectra, its intensity is uniformly the lowest of the three (its integrated intensity is $1-3 \%$ of that of the total intensity of the three bands).

Assignments of bands associated with P-O vibrations in $\mathrm{P}$ bearing aluminosilicate glasses have been summarized by Gan and Hess (1992). In assigning the bands due to dissolved phosphorus in the present spectra, the assignments of Gan and Hess (1992) will be followed for the most part because their assignments were supported by ${ }^{31} \mathrm{P}$ NMR data, and those assignments also were consistent with available vibrational spectroscopic and NMR data (Gan and Hess 1992 and references therein). A more detailed ${ }^{31} \mathrm{P}$ NMR study was published recently by Toplis and Schaller (1998). Their data and those of Gan and Hess (1992) are in general agreement. The band near $950 \mathrm{~cm}^{-1}$ at 25 ${ }^{\circ} \mathrm{C}$ (lower frequency at higher temperatures) is assigned to $\mathrm{P}-\mathrm{O}$ stretching in orthophosphate units $\left(\mathrm{PO}_{4}\right)$. The band near 1000 $\mathrm{cm}^{-1}$ at $25^{\circ} \mathrm{C}$ (and again the frequency decreases with increas-
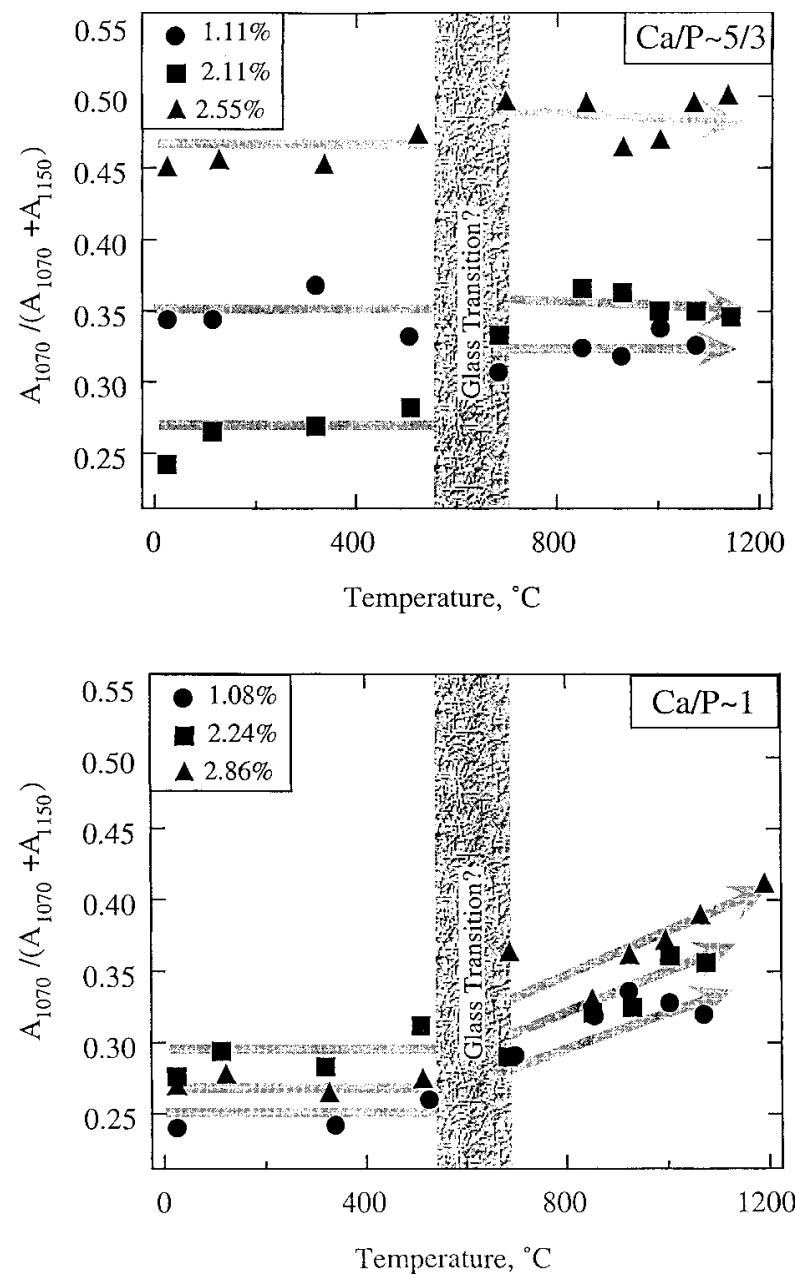

FIGURE 7. Ratio of integrated intensity (area) of 1070 and 1150 $\mathrm{cm}^{-1}$ bands in glasses and melts as a function of temperature. Percent values denote weight percent of $\mathrm{P}_{2} \mathrm{O}_{5}$ in the sample. Shaded region (Glass Transition?) represents temperature range within which the glass transition temperatures for these compositions most likely would be found (see text for detailed discussion).

ing temperature) is assigned to $\mathrm{P}-\mathrm{O}$ stretching in pyrophosphate units $\left(\mathrm{P}_{2} \mathrm{O}_{7}\right)$, and that one near $1120 \mathrm{~cm}^{-1}$ is probably due to $\mathrm{P}$ $\mathrm{O}$ stretching in units that may resemble three-dimensionally interconnected structure of berlinite $\left(\mathrm{AlPO}_{4}\right)$.

\section{DISCUSSION}

From the assignments above, $\mathrm{AlPO}_{4}$ complexing is an important part of the $\mathrm{P}$ solution mechanism in peraluminous aluminosilicate melts, a conclusion also consistent with other studies of $\mathrm{P}$ solution mechanisms in peraluminous aluminosilicate glasses (e.g., Reynard and Toplis 1997; Mysen et al. 1997; Mysen 1998a; Toplis and Schaller 1998). Positive correlation between the proportion of excess $\mathrm{Al}^{3+}$ (increasing $\mathrm{A} / \mathrm{CNK}$ value above 1) and apatite solubility in aluminosilicate melts (Pichavant et al. 1992; Wolf and London 1994) is also consistent with this simple solution model. 

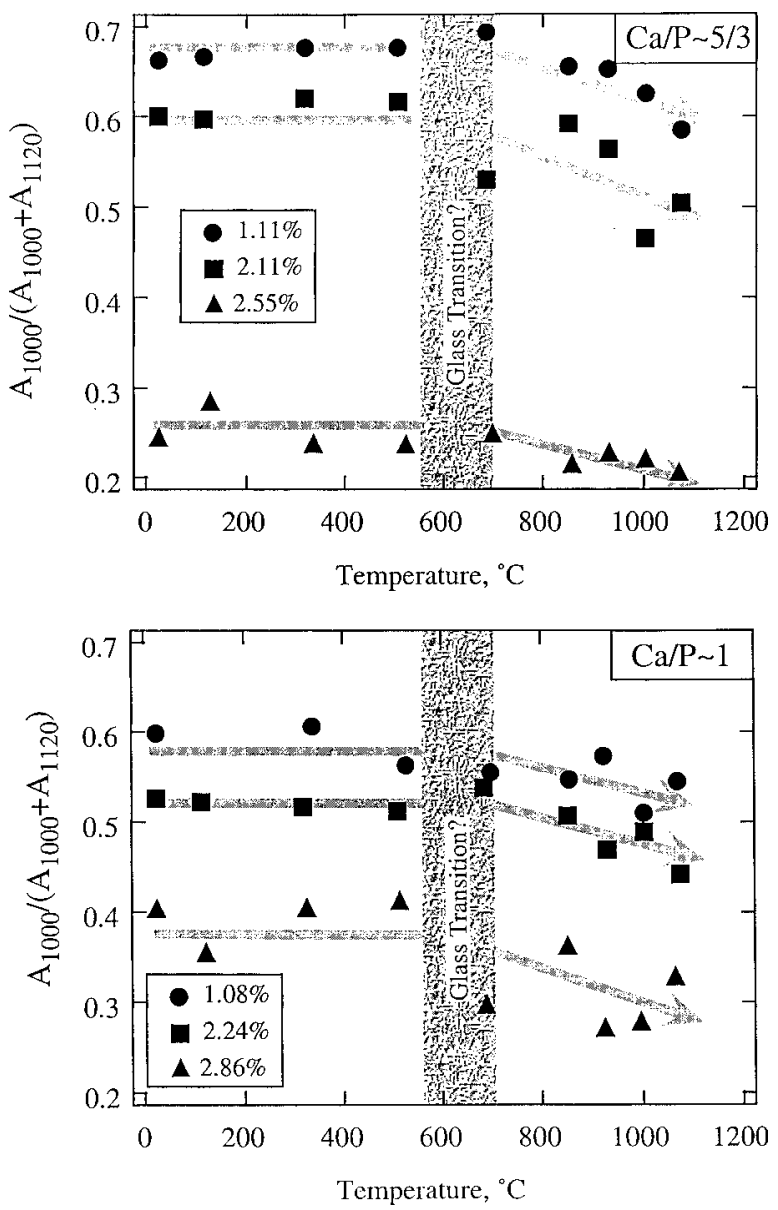

FIGURE 8. Ratio of integrated intensity (area) of 1000 and 1120 $\mathrm{cm}^{-1}$ bands in glasses and melts as a function of temperature. Percent values denotes weight percent of $\mathrm{P}_{2} \mathrm{O}_{5}$ in the sample. Shaded region (Glass Transition?) represents temperature range within which the glass transition temperatures for these compositions most likely would be found (see text for detailed discussion).

An additional complexity to this model was introduced by Mysen et al. (1997) based on Raman spectra obtained at $25^{\circ} \mathrm{C}$ on the same glasses as those used for starting materials in the present study. They suggested that the band near $1250 \mathrm{~cm}^{-1}$ might be due to P-O-Si cross-linking in a P-bearing aluminosilicate network. This band is also inferred to be present in the spectra of $25^{\circ} \mathrm{C}$ glass reported here (see region marked $\mathrm{C}$ in the difference spectra in Fig. 5). However, the intensity of this band diminishes rapidly with increasing temperature and is insignificant or absent in spectra of high-temperature melts. Evidently, if there is Si-O-P cross-linking in the glasses, spectroscopic evidence for those cross-linkages cannot be discerned in the high-temperature, peraluminous silicate melts.

In the present high-temperature study, there is also evidence for pyro- and orthophosphate complexes in addition to the Alphosphate complex similar to those found in peralkaline, metaluminous, and peraluminous melts and glasses in the system $\mathrm{Na}_{2} \mathrm{O}-\mathrm{Al}_{2} \mathrm{O}_{3}-\mathrm{SiO}_{2}-\mathrm{P}_{2} \mathrm{O}_{5}$ (Mysen 1998a). Those conclusions were further supported by ${ }^{31} \mathrm{P}$ NMR data on the glasses in that study (Cody and Mysen, unpublished). Pyrophosphate $\left(\mathrm{P}_{2} \mathrm{O}_{7}^{4-}\right)$ appears in all compositions and at all temperatures, whereas evidence for orthophosphate $\left(\mathrm{PO}_{4}^{3-}\right)$ is only found for materials in the $\mathrm{Ca} / \mathrm{P} \sim 5 / 3$ series. In other words, the series of compositions with the highest $(\mathrm{Ca}+\mathrm{Na}+\mathrm{K}) / \mathrm{P}$ show a wider range in types of phosphate complexing.

Even in the $\mathrm{Ca} / \mathrm{P} \sim 5 / 3$ composition series, the integrated intensity of the $950 \mathrm{~cm}^{-1}$ band assigned to $\mathrm{P}-\mathrm{O}$ stretching in $\mathrm{PO}_{4}^{3-}$ represents $<3 \%$ of the total integrated intensity of P-O stretch bands. Because the Raman cross-sections for these vibrations are not known, these integrated intensities cannot be transformed quantitatively to abundance of the individual species. However, if the relative values of the cross sections for Si-O vibrations in analogous silicates can be taken as a guide (see for example, Mysen 1995), the Raman cross-sections for P-O stretching increase as the phosphate complex becomes less polymerized. Therefore, the intensity ratio of the $950 \mathrm{~cm}^{-1}$ band relative to the sum of integrated intensities of the 950, 1000, and $1120 \mathrm{~cm}^{-1}$ band would be a maximum value for the relative abundance of orthophosphate complexes. The relative abundance of $\mathrm{PO}_{4}^{3-}$ units in the $\mathrm{Ca} / \mathrm{P} \sim 5 / 3$ series of compositions does not exceed $\sim 3 \%$ of the total abundance of phosphate complexes in the melts and glasses.

The intensity of the $950 \mathrm{~cm}^{-1}$ band is also so low that variations in integrated intensities with temperature are buried in the scatter of the data and, therefore will not be considered further. There are, however, systematic relationships between the integrated intensities of the $\sim 1000 \mathrm{~cm}^{-1}$ band (P-O stretching in $\mathrm{P}_{2} \mathrm{O}_{7}^{4-}$ complexes) and those of the $\sim 1120 \mathrm{~cm}^{-1}$ band ( $\mathrm{P}-$ $\mathrm{O}$ stretching in three-dimensionally interconnected $\mathrm{AlPO}_{4}$ complexes). This ratio, $A_{1000} /\left(A_{1000}+A_{1120}\right)$, is correlated negatively with total $\mathrm{P}_{2} \mathrm{O}_{5}$ content at any temperature (Fig. 8). This correlation leads to the suggestion of decreasing relative abundance of $\mathrm{P}_{2} \mathrm{O}_{7}^{4}$ complexes in the melts as they become more aluminous.

The formation of $\mathrm{P}_{2} \mathrm{O}_{7}^{4}$ and $\mathrm{AlPO}_{4}$ complexes can be accomplished via interaction between $\mathrm{Al}^{3+}$ in the aluminosilicate network $\left(\mathrm{AlO}_{2}\right)^{3}$ and dissolved $\mathrm{P}_{2} \mathrm{O}_{5}$ :

$$
4 \mathrm{AlO}_{2}+3 \mathrm{P}_{2} \mathrm{O}_{5} \leftrightarrow \mathrm{P}_{2} \mathrm{O}_{7}+4 \mathrm{AlPO}_{4} .
$$

Equation 1 is conceptually similar to that proposed by Toplis and Dingwell (1996) based on structural interpretation of melt viscosity data, although they proposed such a mechanism to form meta- $\left(\mathrm{PO}_{3}\right)$ rather than pyrophosphate $\left(\mathrm{P}_{2} \mathrm{O}_{7}\right)$. The solution mechanism illustrated with Equation 1 is also consistent with the observation (London et al. 1993) that addition of $\mathrm{P}_{2} \mathrm{O}_{5}$ to the haplogranite system causes expansion of the liquidus volume of quartz relative to that of feldspar. That expansion is a direct result of the formation of $\mathrm{AlPO}_{4}$ complexes at the expense of $\mathrm{AlO}_{2}$ complexes in the melt. The alkalis required for charge-compensation of $\mathrm{Al}^{3+}$ in the $\mathrm{AlO}_{2}$ complexes are transferred to the pyrophosphate from the $\mathrm{AlO}_{2}$ complex.

${ }^{3} \mathrm{Al}^{3+}$ in the aluminosilicate network requires alkalis or calcium for charge-balance. For simplicity, in describing these relations, neither the charge-balancing metal nor the formal electrical charge of the anionic complexes are shown. 
Reaction 1 alone cannot, however, account for all the spectroscopic observations and their structural interpretations, because it does not offer a mechanism by which the abundance of $\mathrm{AlPO}_{4}$ complexes increases relative to $\mathrm{P}_{2} \mathrm{O}_{7}$ with increasing $\mathrm{P}_{2} \mathrm{O}_{5}$ contents and A/CNK of the melts (Fig. 8). This latter feature can, however, simply be accommodated by including the excess alumina in the formation of $\mathrm{AlPO}_{4}$ complexes:

$$
\mathrm{Al} \text { (excess) }+3 \mathrm{AlO}_{2}+2 \mathrm{P}_{2} \mathrm{O}_{5} \leftrightarrow 4 \mathrm{AlPO}_{4} \text {. }
$$

In Equation $2 \mathrm{Al}$ (excess) denotes $\mathrm{Al}^{3+}$ in excess of that for which there are alkalis and alkaline earths for electrical chargebalance of $\mathrm{Al}$ in tetrahedral coordination. The $\mathrm{AlO}_{2}$ complex represents $\mathrm{Al}^{3+}$ in tetrahedral coordination as a part of the aluminosilicate network.

For each composition, $\mathrm{A}_{1000} /\left(\mathrm{A}_{1000}+\mathrm{A}_{1120}\right)$ remains constant from room temperature to $650 \pm 100^{\circ} \mathrm{C}$, followed by a slight decrease at higher temperatures (Fig. 8). In this approximate temperature range $\left(650 \pm 100^{\circ} \mathrm{C}\right)$, the integrated intensity ratio, $\mathrm{A}_{1070} /$ $\left(A_{1070}+A_{1150}\right)$, begins to increase (Fig. 7) suggesting that the materials become somewhat less polymerized as the relative abundance of pyrophosphate units decreases relative to Al-phosphate. These transitions (Figs. 7 and 8) might be related to transgression across the glass transition temperature in these glasses. These structural changes across the glass transition are similar to those observed in the simpler systems $\mathrm{Na}_{2} \mathrm{O}-\mathrm{SiO}_{2}-\mathrm{P}_{2} \mathrm{O}_{5}$ (Mysen 1996) and $\mathrm{Na}_{2} \mathrm{O}-\mathrm{Al}_{2} \mathrm{O}_{3}-\mathrm{SiO}_{2}-\mathrm{P}_{2} \mathrm{O}_{5}$ (Mysen 1998a). Although the glass transformation temperatures for the present compositions are not known, for the present purposes, these may be estimated semiquantitatively from the simple relationship, $T_{\mathrm{g}}=2 / 3 \cdot T_{\mathrm{liq}}$, where $T_{\text {liq }}$ and $T_{\mathrm{g}}$ are the liquidus and glass transition temperatures $(\mathrm{K})$, respectively. ${ }^{4}$ The liquidus temperatures were estimated from those of the end-member ternary systems, $\mathrm{Na}_{2} \mathrm{O}-\mathrm{Al}_{2} \mathrm{O}_{3}-\mathrm{SiO}_{2}$, $\mathrm{K}_{2} \mathrm{O}-\mathrm{Al}_{2} \mathrm{O}_{3}-\mathrm{SiO}_{2}$, and $\mathrm{CaO}-\mathrm{Al}_{2} \mathrm{O}_{3}-\mathrm{SiO}_{2}$ (Osborn and Muan 1960a, $1960 \mathrm{~b}, 1960 \mathrm{c})$ by assuming ideal mixing of the aluminate components and using the heat of fusion data for tridymite (liquidus phase for these compositions) from Richet (1986). The liquidus temperatures of $\mathrm{P}$-free compositions so calculated range from $\sim 1350$ to $\sim 1500{ }^{\circ} \mathrm{C}$. The effect of dissolved $\mathrm{P}_{2} \mathrm{O}_{5}$ on the liquidus temperatures was also calculated in this manner, which results in liquidus temperatures in the P-bearing systems in the range $1050-1200{ }^{\circ} \mathrm{C}$. From these estimated liquidus temperatures, the glass transition temperatures for the compositions studied are in the range of $550-700{ }^{\circ} \mathrm{C}$. This range is marked in Figures 7 and 8 .

Although the ratios of integrated intensities as a function of temperature display some scatter, ${ }^{5}$ it is evident that the integrated intensity of the $1000 \mathrm{~cm}^{-1}$ band $\left(\mathrm{P}-\mathrm{O}\right.$ stretching in $\mathrm{P}_{2} \mathrm{O}_{7}$ complexes) decreases relative to that of the $1120 \mathrm{~cm}^{-1}$ band (P$\mathrm{O}$ stretching in $\mathrm{AlPO}_{4}$ complexes) as the estimated glass tran-

${ }^{4}$ In a comparison of $T_{\mathrm{g}}$ values calculated in this manner with measured $T_{\mathrm{g}}$ values, Mysen (1998b) found that the calculated $T_{\mathrm{g}}$ values were within $\pm 10 \%$ of the measured values. $\mathrm{A} \pm 10 \%$ uncertainty results in the ranges shown in Figures 7 and 8. Given the scatter in the data in those figures, a $10 \%$ uncertainty in the $T_{\mathrm{g}}$ values does not affect the overall conclusions.

${ }^{5}$ This is particularly so in Figure 6, where the integrated intensity of the $1070 \mathrm{~cm}^{-1}$ band is considerably uncertain due to possible intereference from unresolved Raman bands. sition temperature range is crossed (Fig. 8). A possible reaction expressing the relationship between $\mathrm{P}_{2} \mathrm{O}_{7}$ and $\mathrm{AlPO}_{4}$ is

$$
4 \mathrm{AlO}_{2}+12 \mathrm{Q}^{4}+2 \mathrm{P}_{2} \mathrm{O}_{7} \leftrightarrow 4 \mathrm{AlPO}_{4}+12 \mathrm{Q}^{3}
$$

which shifts to the right as the temperature is increased above the suggested glass transition temperatures. This is a depolymerization reaction (increase in abundance ratio, $Q^{3} / Q^{4}$ ) consistent with the increased ratio of integrated areas, $\mathrm{A}_{1070} /$ $\left(A_{1070}+A_{1150}\right)$ (Fig. 7). Without calibration of these intensity ratios, quantitative assessment of the abundances of individual complexes cannot be carried out. It is clear, however, that the P-bearing aluminosilicate melts are less polymerized than their corresponding glasses.

\section{CONCLUDING REMARKS}

The dominant phosphate complexing mechanism in peraluminous haplogranite composition melts and glasses at atmospheric pressure is that of an $\mathrm{AlPO}_{4}$-type complex. A small fraction of ortho- and pyrophosphate complexing is also observed. The fraction of the latter complexes becomes more important as $\mathrm{Ca} / \mathrm{P}$ of the melts and glasses is increased. With increasing temperature above that of the glass transition, the $\mathrm{AlPO}_{4}$-complexes becomes more important relative to pyrophosphate complexes. This transformation is accompanied by depolymerization of the aluminosilicate network portion of the melt system. These temperature-dependent structural changes cannot be quenched in as a melt is transformed to a glass.

\section{ACKNOWLEDGMENTS}

A majority of this work was conducted while one of us (B.O.M.) visited CNRS-CRSCM in Orleans, France, during the summer of 1994. The hospitality extended by CNRS is greatly appreciated. Critical reviews by G. Morgan and an unidentified reviewer improved the manuscript. This research was partially supported by PICS-CIW grant no. 142, and by NSF grant no. EAR-961443 (B.O.M.).

\section{REFERENCES CITED}

Daniel, I., Gillet, P., Poe, B.T., and McMillan, P.F. (1995) In-situ high-temperature Raman spectroscopic studies of aluminosilicate liquids. Physics and Chemistry of Minerals, 22, 74-86.

Dingwell, D.B., Knoche, R., and Webb, S.L. (1993) The effect of $\mathrm{P}_{2} \mathrm{O}_{5}$ on the viscosity of haplogranitic liquid. European Journal of Mineralogy, 5, 133-140.

Dupree, R., Holland, D., Mortuza, J.A., Collins, J.A., and Lockyer, M.W.G. (1989) Magic angle spinning NMR of alkali phospho-alumino-silicate glasses. Journal of Non-Crystalline Solids, 112, 111-119.

Gan, H., and Hess, P.C. (1992) Phosphate speciation in potassium aluminosilicate glasses. American Mineralogist, 77, 495-506.

Ghazot, G., Menzies, M.A., and Hart, B. (1996) Determination of partition coefficients between apatite, clinopyroxene, amphibole, and melt in natural spinel lherzolites from Yemen; Implications for wet melting of the lithospheric mantle. Geochimica et Cosmochimica Acta, 60, 423-427.

Green, T.H. and Watson, E.B. (1982) Crystallization of apatite in natural magmas under high pressure hydrous conditions, with particular reference to orogenic rock series. Contributions to Mineralogy and Petrology, 79, 96-105.

Gwinn, R., and Hess, P.C. (1993) The role of phosphorus in rhyolitic liquids as determined from the homogeneous iron redox equilibrium. Contributions to Mineralogy and Petrology, 113, 424-435.

Kosinski, S.G., Krol, D.M., Duncan, T.M., Douglass, D.C., MacChesney, J.B., and Simpson, J.R. (1988) Raman and NMR spectroscopy of $\mathrm{SiO}_{2}$ glasses co-doped with $\mathrm{Al}_{2} \mathrm{O}_{3}$ and $\mathrm{P}_{2} \mathrm{O}_{5}$. Journal of Non-Crystalline Solids, 105(1,2), 45-52.

Kushiro, I. (1975) On the nature of silicate melt and its significance in magma genesis: Regularities in the shift of liquidus boundaries involving olivine pyroxene, and silica materials. American Journal of Science, 275, 411-431.

Lacey, E.D. (1963) Aluminum in glasses and melts. Physics and Chemistry of Glasses, 4, 234-238.

London, D. (1987) Internal differentiation of rare earth-element pegmatites: Effects of boron, phosphorous, and fluorine. Geochimica et Cosmochimica Acta, 51, $403-420$.

London, D., Loomis, J.L., Huang, W., and Morgan, G.B. (1990) Behavior and effect 
of phosphorous in the system Ab-Or-Qz- $\mathrm{H}_{2} \mathrm{O}$ at $200 \mathrm{MPa}\left(\mathrm{H}_{2} \mathrm{O}\right)$. Geol. Soc. Amer. Abstracts with Program 22, 302.

London, D., Morgan, G.B., Babb, H.A., and Loomis, J.L. (1993) Behavior and effects of phosphorus in the system $\mathrm{Na}_{2} \mathrm{O}-\mathrm{K}_{2} \mathrm{O}-\mathrm{Al}_{2} \mathrm{O}_{3}-\mathrm{SiO}_{2}-\mathrm{P}_{2} \mathrm{O}_{5}-\mathrm{H}_{2} \mathrm{O}$ at $200 \mathrm{MPa}$ $\left(\mathrm{H}_{2} \mathrm{O}\right)$. Contributions to Mineralogy and Petrology, 113, 450-465.

Long, D.A. (1977) Raman Spectroscopy. 276 p. McGraw-Hill, New York.

McMillan, P., Piriou, B., and Navrotsky, A. (1982) A Raman spectroscopic study of glasses along the joins silica-calcium aluminate, silica-sodium aluminate and silica-potassium aluminate. Geochimica et Cosmochimica Acta, 46, 2021-2037.

McMillan, P.F., Poe, B.T., Gillet, P., and Reynard, B. (1994) A study of SiO2 glass and supercooled liquid to $1950 \mathrm{~K}$ via high-temperature Raman spectroscopy. Geochimica et Cosmochimica Acta, 58, 3653-3664.

McMillan, P.F., Wolf, G.H., and Poe, B.T. (1992) Vibrational spectroscopy of silicate liquids and glasses. Chemical Geology, 96, 351-366.

Mysen, B.O. (1992) Iron and phosphorus in calcium silicate quenched melts. Chemical Geology, 98, 175-202.

- (1995) Structural behavior of $\mathrm{Al}^{3+}$ in silicate melts: In-situ, high-temperature measurements as a function of bulk chemical composition. Geochimica et Cosmochimica Acta, 59, 455-474.

(1996) Phosphorous speciation changes across the glass transition in highly polymerized alkali silicate glasses and melts. American Mineralogist, 81, 15311534 .

(1998a) Phosphorus solubility mechanisms in haplogranitic aluminosilicate glass and melt: Effect of temperature and aluminum content. Contributions to Mineralogy and Petrology, 133, 38-50.

(1998b) Structure and properties of magmatic liquids: From haplobasalt to haploandesite. Geochimica et Cosmochimica Acta, in press.

Mysen, B.O. and Frantz, J.D. (1992) Raman spectroscopy of silicate melts at magmatic temperatures: $\mathrm{Na}_{2} \mathrm{O}-\mathrm{SiO}_{2}, \mathrm{~K}_{2} \mathrm{O}-\mathrm{SiO}_{2}$, and $\mathrm{Li}_{2} \mathrm{O}-\mathrm{SiO}_{2}$ binary compositions in the temperature range $25^{\circ}-1475^{\circ} \mathrm{C}$. Chemical Geology, $96,321-332$.

(1993) Structure of silicate melts at high temperature: In-situ measurements in the system $\mathrm{BaO}_{-} \mathrm{SiO}_{2}$ to $1669^{\circ} \mathrm{C}$. American Mineralogist, 78, 699-1669.

Mysen, B.O., Ryerson, F.J., and Virgo, D. (1981) The structural role of phosphorous in silicate melts. American Mineralogist, 66, 106-117.

Mysen, B.O., Finger, L.W., Seifert, F.A., and Virgo, D. (1982) Curve-fitting of Raman spectra of amorphous materials. American Mineralogist, 67, 686-696.

Mysen, B.O., Holtz, F., Pichavant, M., Beny, J.-M., and Montel, J.-M. (1997) Solution mechanisms of phosphorus in quenched hydrous and anhydrous granitic glass as a function of peraluminosity. Geochimica et Cosmochimica Acta, 61 , 3913-3926.

Neuville, D.R., and Mysen, B.O. (1996) Role of aluminum in the silicate network: In-situ, high-temperature study of glasses and melts on the join $\mathrm{SiO}_{2}-\mathrm{NaAlO}_{2}$. Geochimica et Cosmochimica Acta, 60, 1727-1738.

Osborn, E.F. and Muan, A. (1960a) Phase equilibrium diagrams for ceramists. Plate 4. The system $\mathrm{Na}_{2} \mathrm{O}-\mathrm{Al}_{2} \mathrm{O}_{3}-\mathrm{SiO}_{2}$. American Ceramic Society, Columbus $\mathrm{OH}$.

(1960b) Phase equilibrium diagrams for ceramists. Plate 5. The system $\mathrm{K}_{2} \mathrm{O}$ $\mathrm{Al}_{2} \mathrm{O}_{3}-\mathrm{SiO}_{2}$. American Ceramic Society, Columbus $\mathrm{OH}$.

(1960c) Phase equilibrium diagrams of oxide systems. Plate 2. The System $\mathrm{CaO}-\mathrm{Al}_{2} \mathrm{O}_{3}-\mathrm{SiO}_{2}$. American Ceramic Society, Columbus OH.

Pichavant, M., Herrera, J.V., Boulmier, S., Brigueu, L., Joron, J.-L., Juteau, L.M., Michard, A., Sheppard, S.M.F., Treuil, M., and Vernet, M. (1987) The Macusani glasses, SE Peru: Evidence of chemical fractionation of peraluminous magmas. In B.O. Mysen, Ed., Magmatic Processes: Physicochemical Principles, p. 359374. Geochemical Society.

Pichavant, M., Montel, J.-M., and Richard, L.R. (1992) Apatite solubility in peraluminous liquids: Experimental data and an extension of the Harrison model. Geochimica et Cosmochimica Acta, 56, 3855-3861.

Poe, B.T., McMillan, P.F., Cote, B., Massiot, D., and Coutoures, J.-P. (1992) $\mathrm{SiO}_{2-}$ $\mathrm{Al}_{2} \mathrm{O}_{3}$ liquids: In-situ study by high-temperature ${ }^{27} \mathrm{Al}$ NMR spectroscopy and molecular dynamics simulations. Journal of Physical Chemistry, 96, 8220-8224.

Reynard, B. and Toplis, M. (1997) The structural role of phosphorus in $\mathrm{Na}_{2} \mathrm{O}-\mathrm{Al}_{2} \mathrm{O}_{3^{-}}$ $\mathrm{SiO}_{2}-\mathrm{P}_{2} \mathrm{O}_{5}$ glasses and melts: High-temperature Raman spectroscopic results. Terra Nova, 9 (Abstract Supplement 1), 483.

Richet, P., Ingrin, J., Mysen, B.O., Courtial, P., and Gillet, P. (1994) Premelting effects in minerals: an experimental study. Earth and Planetary Science Letters, $121,589-600$.

Ryerson, F.J. (1985) Oxide solution mechanisms in silicate melts: Systematic variations in the activity coefficient of $\mathrm{SiO}_{2}$. Geochimica et Cosmochimica Acta, 49, $637-651$.

Sato, R.K., McMillan, P.F., Dennison, P., and Dupree, R. (1991) A structural investigation of high alumina glasses in the $\mathrm{CaO}-\mathrm{Al}_{2} \mathrm{O}_{3}-\mathrm{SiO}_{2}$ system via Raman and magic angle spinning nuclear magnetic resonance spectroscopy. Physics and Chemistry of Glasses, 32(4), 149-160.

Seifert, F.A., Mysen, B.O., and Virgo, D. (1982) Three-dimensional network structure in the systems $\mathrm{SiO}_{2}-\mathrm{NaAlO}_{2}, \mathrm{SiO}_{2}-\mathrm{CaAl}_{2} \mathrm{O}_{4}$ and $\mathrm{SiO}_{2}-\mathrm{MgAl}_{2} \mathrm{O}_{4}$. American Mineralogist, 67, 696-711.

Toplis, M.J. and Dingwell, D.W. (1996) The variable influence of $\mathrm{P}_{2} \mathrm{O}_{5}$ on the viscosity of melts of differing alkali/aluminum ratio: Implications for the structural role of phosphorus in silicate melts. Geochimica et Cosmochimica Acta, 60, 4107-4121.

Toplis, M.J. and Schaller, T. (1998) A ${ }^{31} \mathrm{P}$ MAS NMR study of glasses in the system $\mathrm{xNa}_{2} \mathrm{O}-(1-\mathrm{x}) \mathrm{Al}_{2} \mathrm{O}_{3}-2 \mathrm{SiO}_{2}-\mathrm{yP}_{2} \mathrm{O}_{5}$. Journal of Non-Crystalline Solids, 224, 57-68.

Toplis, M.J., Dingwell, D.B., and Libourel, G. (1994) The effect of phosphorus on the iron redox ratio, viscosity, and density of an evolved ferro-basalt. Contributions to Mineralogy and Petrology, 117, 293-304.

Watson, E.B. (1976) Two-liquid partition coefficients: Experimental data and geochemical implications. Contributions to Mineralogy and Petrology, 56, 119-134.

(1980) Apatite and phosphorous in mantle source regions: An experimental study of apatite/melt equilibria at pressures to 25 kbar. Earth and Planetary Science Letters, 51, 322-335.

Wolf, M.B., and London, D. (1994) Apatite dissolution into peraluminous haplogranitic melts: An experimental study of solubilities and mechanisms. Geochimica et Cosmochimica Acta, 58, 4127-4145.

Wyllie, P.J., and Tuttle, O.F. (1964) Experimental investigation of silicate systems containing two volatile components. III. The effects of $\mathrm{SO}_{3}, \mathrm{P}_{2} \mathrm{O}_{5}, \mathrm{HCl}$, and $\mathrm{Li}_{2} \mathrm{O}$ in addition to $\mathrm{H}_{2} \mathrm{O}$ on the melting temperatures of albite and granite. American Journal of Science, 262, 930-939.

MANUSCRIPT RECEIVED MARCH 23, 1998

MANUSCRIPT ACCEPTED APRIL 29, 1999

PAPER HANDLED BY DAVID LONDON 